DEPARTMENT OF THE INTERIOR

UNITED STATES GEOLOGICAL SURVEY

\title{
AEROMAGNETIC MAP OF NEVADA: COLOR CODED INTENSITIES
}

By Isidore Zietz, Francis P. Gilbert, and John R. Kirby

Prepared in cooperation with the NEVADA BUREAU OF MINES AND GEOLOGY 